\title{
Cashew nut meal subjected to prolonged storage for quail feeding
}

\author{
Nadja Naiara Pereira Farias ${ }^{1 *}$, Ednardo Rodrigues Freitas ${ }^{1}$, Regina Patrícia de Souza Xavier ${ }^{1}$, \\ Nádia de Melo Braz', Davyd Herik Souza', Thais Cruz Lopes Tavares ${ }^{1}$
}

${ }^{1}$ Universidade Federal do Ceará, Departamento de Zootecnia, Campus do Pici, Fortaleza, CE, Brazil.

\begin{abstract}
The objective of this study was to evaluate the oxidative stability of cashew nut meal (CNM) at 180 days of storage and the effects of its use in the feed of meat quails. A total of 280 animals at seven days of age, of both sexes, were distributed in a completely randomized design with five treatments, in a $2 \times 2+1$ factorial arrangement, and seven replicates of eight birds each. The treatments were a control diet without CNM and diets containing levels of 12.5 or $25 \%$ of new CNM (NCNM) or stored for 180 days (SCNM). The lipid oxidation of the brans was evaluated by determining the acidity index and peroxide index. The parameters evaluated were the quail performance, metabolizable coefficients and energy of diets, carcass characteristics, relative weights of the liver and pancreas, and bone parameters. The acidity of cashew nut meal was $4.66 \%$ and 6.16 (\% in oleic acid) for NCNM and SCNM, respectively. Independent of the storage, inclusion of CNM resulted in higher metabolizable energy values in the diet, reduced intake, and, because weight gain did not vary, feed conversion improved compared with the control treatment. Carcass traits, relative weights of liver and pancreas, as well as bone growth and quality were not affected by dietary treatments. Despite the hydrolytic rancidity, CNM can be used in the diets for meat quails at up to $25 \%$ of inclusion.
\end{abstract}

Key Words: carcass characteristics, feed intake, feed conversion, metabolizable energy, quail, weight gain

\section{Introduction}

Corn grain and soybean meal together account for up to $96 \%$ of the composition of quail diets. Because the supply, and consequently the price of these ingredients oscillate throughout the year, the technical and scientific community has sought feeding alternatives for the poultry industry that can reduce costs without compromising the performance of birds.

In the Northeast of Brazil, especially in Ceará State, cashew nut meal (CNM), a noteworthy byproduct derived from the processing of the cashew nut, is among alternative feeds. Its high ether extract content makes this feed promising for use in diets as a source of energy (Freitas et al., 2006). However, its richness in lipids, made up mostly of unsaturated fatty acids, predominantly of miristic $(0.03 \%)$, palmitoleic $(0.54 \%)$, palmitic $(10.70 \%)$, linolenic $(0.32 \%)$, linoleic

Received: February 29, 2016

Accepted: February 2, 2017

*Corresponding author: nadja_naiara@hotmail.com

http://dx.doi.org/10.1590/S1806-92902017000700004

How to cite: Farias, N. N. P.; Freitas, E. R.; Xavier, R. P. S.; Braz, N. M.; Souza, D. H. and Tavares, T. C. L. 2017. Cashew nut meal subjected to prolonged storage for quail feeding. Revista Brasileira de Zootecnia 46(7):576-583.

Copyright (C) 2017 Sociedade Brasileira de Zootecnia. This is an Open Access article distributed under the terms of the Creative Commons Attribution License (http://creativecommons.org/licenses/by/4.0/), which permits unrestricted use, distribution, and reproduction in any medium, provided the original work is properly cited.
$(16.88 \%)$, oleic $(61.15 \%)$, margaric $(0.12 \%)$, and estearic acids (9.33\%) (Venkatachalam and Sathe, 2006), makes it susceptible to the development of oxidative rancidity (Lopes et al., 2009). Hydrolytic rancidity may also appear during the storage of the meal (Lopes et al., 2009).

Rancidification can be a problem in the use of some feeds, as the free radicals originated during the oxidative process propagate, destroying the essential fatty acids, proteins, liposoluble proteins, and carotenoids of feeds (Leeson and Summers, 2001). In cases in which this destruction is more severe, birds may display symptoms of deficiency-related diseases such as encephalomalacia, exudative diathesis, muscular dystrophy, and necrosis of tissues in various organs (Cabel et al., 1988). Moreover, in the final stage of the oxidation process, several compounds are formed, which alter the flavor of feeds, consequently influencing feed intake, besides their toxic effects on the organism (Wang et al., 1997).

The objective of this study was to evaluate the oxidative stability of cashew nut meal during storage (SCNM) and the effects of its use in the feeding of meat quails on growth performance, carcass traits, and relative weights of the liver and pancreas, as well as bone parameters.

\section{Material and Methods}

The experiment was approved by the local Committee of Ethics on Animal Research in a meeting held on June 24, 
2013, under case no. 20/2013 for the use of experimental animals. The referred experiment complies with the Ethical Principles of Animal Experimentation adopted by the Brazilian College of Animal Experimentation.

A total of 280 meat quails (Coturnix coturnix) at seven days of age, of both sexes, were distributed in a completely randomized design with five treatments and seven replicates with eight birds each. Treatments were organized in a $2 \times 2+1$ factorial arrangement, in which the following factors were evaluated: storage (stored and new meal) and level of inclusion (12.5 and 25\%), in addition to an additional treatment (control diet).

To obtain the meals for the study, a load of $100 \mathrm{~kg}$ of $\mathrm{CNM}$ was initially acquired soon after industrial processing. This meal, conditioned in a raffia bag, was stocked on a wooden platform in an open, dry, well-ventilated place protected from light for 180 days. This was used as the stored cashew nut meal (SCNM) treatment. At the end of this period, a new $100-\mathrm{kg}$ load of CNM was acquired and this was used as the new cashew nut meal (NCNM) treatment. The two meals were acquired from the same processing industry, from the same batch of cashew nuts.

The two meals were analyzed for lipid stability, by determining their acidity index (\% in oleic acid) and peroxide value (meq $\mathrm{kg}^{-1}$ ) (Anfar, 2005). Regardless of the results obtained for lipid oxidation, they were used to make up the experimental diets.

The chemical composition values and metabolizable energy of cashew nut meal were obtained from Silva et al. (2008) and the other ingredients of rations were considered the values presented by Rostagno et al. (2011). The nutritional requirements for quail presented in the NRC (1994) were also considered, so that all feeds were formulated to be isocaloric and isonutritive, made on Super Crac 5.0 software (Table 1).

A total of 400 quails at one day of age were weighed and housed in a circle of protection provided with a heat source, adapted bird drinkers, and tray-type feeders sufficient for all quails. From one to seven days of age, the birds were fed the control diet and managed according to the technical recommendations for the period. At seven days old, birds were weighed again, then distributed according to their weight into the different treatments to form plots with the same average weight, according to recommendations proposed by Sakomura and Rostagno (2007) for trials with birds. In this phase, the birds from each plot were housed in galvanized-wire cages $(52 \times 26 \times 20 \mathrm{~cm})$ that contained trough feeders and adapted bird drinkers. At that age, the birds were vaccinated against Newcastle disease by ocular application.
In the rearing period, birds received $24 \mathrm{~h}$ of light (natural + artificial). The artificial illumination in the shed was provided by $40-\mathrm{W}$ fluorescent light bulbs, distributed $2.40 \mathrm{~m}$ above the floor so as to allow uniform illumination for all birds. The environmental variables of temperature and relative air humidity within the shed were measured with a thermo-hygrometer. Data were recorded daily and readings were taken at 08.00 and $16.00 \mathrm{~h}$.

At the end of the experimental period, the average maximum and minimum temperatures and the average relative air humidity were calculated. During the experiment, the average maximum and minimum temperatures recorded in the shed were 32.12 and $29.73{ }^{\circ} \mathrm{C}$, respectively. The average relative air humidity was $78 \%$.

During the entire experimental period, from 7 to 42 days of age, diets and water were available ad libitum

Table 1 - Composition of the experimental diets for quails of 7-42 days old

\begin{tabular}{|c|c|c|c|c|c|}
\hline \multirow{3}{*}{ Ingredient (kg) } & \multicolumn{5}{|c|}{ Diet } \\
\hline & \multirow{2}{*}{ Control $^{1}$} & \multicolumn{2}{|c|}{ NCNM (\%) } & \multicolumn{2}{|c|}{ SCNM (\%) } \\
\hline & & 12.5 & 25 & 12.5 & 25 \\
\hline Corn & 52.10 & 41.45 & 25.14 & 41.45 & 25.14 \\
\hline NCNM & 0.00 & 12.50 & 25.00 & 0.00 & 0.00 \\
\hline SCNM & 0.00 & 0.00 & 0.00 & 12.50 & 25.00 \\
\hline Soybean meal (45\%) & 42.99 & 39.00 & 36.05 & 39.00 & 36.05 \\
\hline Calcitic limestone & 1.20 & 0.88 & 0.70 & 0.88 & 0.70 \\
\hline Soybean oil & 1.91 & 0.00 & 0.00 & 0.00 & 0.00 \\
\hline Monocalcium phosphate & 0.94 & 1.03 & 1.08 & 1.03 & 1.08 \\
\hline Mineral-vitamin supplement ${ }^{2}$ & 0.40 & 0.40 & 0.40 & 0.40 & 0.40 \\
\hline Common salt & 0.44 & 0.43 & 0.43 & 0.43 & 0.43 \\
\hline DL-methionine & 0.02 & 0.06 & 0.10 & 0.06 & 0.10 \\
\hline Inert & 0.00 & 4.23 & 11.07 & 4.23 & 11.07 \\
\hline L-lysine & 0.00 & 0.02 & 0.03 & 0.02 & 0.03 \\
\hline Total & 100.00 & 100.00 & 100.00 & 100.00 & 100.00 \\
\hline
\end{tabular}

Calculated nutritional level

Metabolizable energy (kcal/kg) $2900 \quad 2890 \quad 2890 \quad 2890 \quad 2890$

$\begin{array}{llllll}\text { Crude protein }(\%) & 23.80 & 23.80 & 23.80 & 23.80 & 23.80\end{array}$

$\begin{array}{llllll}\text { Dry matter }(\%) & 87.40 & 89.33 & 90.88 & 89.33 & 90.88\end{array}$

$\begin{array}{llllll}\text { Ether extract }(\%) & 4.49 & 7.71 & 12.64 & 7.71 & 12.64\end{array}$

$\begin{array}{llllll}\text { Crude fiber (\%) } & 3.45 & 3.03 & 2.57 & 3.03 & 2.57\end{array}$

$\begin{array}{llllll}\text { Acid detergent fiber (\%) } & 5.35 & 7.19 & 8.92 & 7.19 & 8.92\end{array}$

$\begin{array}{llllll}\text { Neutral detergent fiber (\%) } & 12.08 & 13.68 & 14.76 & 13.68 & 14.76\end{array}$

$\begin{array}{llllll}\text { Calcium (\%) } & 0.80 & 0.80 & 0.80 & 0.80 & 0.80\end{array}$

$\begin{array}{llllll}\text { Available phosphorus (\%) } & 0.30 & 0.30 & 0.30 & 0.30 & 0.30\end{array}$

$\begin{array}{llllll}\text { Sodium (\%) } & 0.22 & 0.22 & 0.22 & 0.22 & 0.22\end{array}$

$\begin{array}{llllll}\text { Total lysine (\%) } & 1.32 & 1.31 & 1.30 & 1.31 & 1.30\end{array}$

$\begin{array}{lllllll}\text { Total methionine }+ \text { cystine }(\%) & 0.87 & 0.88 & 0.87 & 0.88 & 0.87\end{array}$

$\begin{array}{llllll}\text { Total methionine (\%) } & 0.50 & 0.54 & 0.57 & 0.54 & 0.57\end{array}$

$\begin{array}{llllll}\text { Total threonine }(\%) & 0.93 & 0.92 & 0.91 & 0.92 & 0.91\end{array}$

$\begin{array}{llllll}\text { Total tryptophan }(\%) & 0.30 & 0.30 & 0.31 & 0.30 & 0.31\end{array}$

${ }^{1}$ Control: without cashew nut meal.

NCNM - new cashew nut meal; SCNM - cashew nut meal stored for 180 days.

${ }^{2}$ Composition per $\mathrm{kg}$ of product: folic acid, $138.00 \mathrm{mg}$; calcium pantothenate $2,750.00 \mathrm{mg}$; antioxidant, $500.00 \mathrm{mg}$; biotin, $13.80 \mathrm{mg}$; cobalt, $25.00 \mathrm{mg}$; copper, $2,500.00 \mathrm{mg}$; choline, $111,450.00 \mathrm{mg}$; iron, $6,250.00 \mathrm{mg}$; iodine, $260.00 \mathrm{mg}$; manganese, $13,000.00 \mathrm{mg}$; methionine, $300.00 \mathrm{~g}$; niacin, $6,875.00 \mathrm{mg}$; pyridoxine, $550.00 \mathrm{mg}$; colistin, $1,750.00 \mathrm{mg}$; riboflavin, $1,375.00 \mathrm{mg}$; selenium, $45.00 \mathrm{mg}$; thiamine, $550.00 \mathrm{mg}$; vitamin A, 2,150,000.00 IU; vitamin B12, 2,750.00 mg; vitamin D3, 555,000.00 IU; vitamin E, 2,750.00 IU; vitamin K, $400.00 \mathrm{mg}$; zinc, $11,100.00 \mathrm{mg}$; silicates, $20,000.00 \mathrm{mg}$. 
and feeders and drinkers were replenished twice daily, at 08.00 and $16.00 \mathrm{~h}$. The evaluated performance parameters were feed intake ( $\mathrm{g} / \mathrm{bird})$, weight gain ( $\mathrm{g} / \mathrm{bird}$ ), and feed conversion $\left(\mathrm{g} \mathrm{g}^{-1}\right)$, with variables corrected for mortality (Sakomura and Rostagno, 2007).

To evaluate the digestibility of nutrients, total excreta collection was performed (Sakomura and Rostagno, 2007) from birds of 14 to 17 days of age. Before the beginning of the experimental feeding phase, quails were feed-deprived for $2 \mathrm{~h}$ to empty their gastrointestinal tract and only the excreta originating from the feed consumed during the assay were collected. This same procedure was adopted to determine the end of the collection period. The excreta from each experimental unit were collected twice daily, in the early morning $(08.00 \mathrm{~h})$ and late afternoon $(16.00 \mathrm{~h})$, in plastic-covered trays placed under each cage. After collections, the excreta were dried in a forced-air circulation oven at $55{ }^{\circ} \mathrm{C}$ for $72 \mathrm{~h}$. Subsequently, they were ground in a knife mill with 1-mm sieve and placed in plastic jars.

Samples of excreta and diets had their dry matter (DM), nitrogen, and gross energy (GE) levels determined (Silva and Queiroz, 2002). The gross energy values of the excreta and diets were determined using a bomb calorimeter PARR (Model 1242, Parr Instrument Co. USA-1984). Based on the results of the analyses, the following were calculated: coefficients of apparent metabolization of DM (CMDM), N $(\mathrm{CMN})$, and GE (CMGE); apparent metabolizable energy (AME); and nitrogen-corrected apparent metabolizable energy (AMEn), according to Sakomura and Rostagno (2007).

At the end of the experimental period (42 days of age), two birds from each plot, one male and one female, were selected to be slaughtered for evaluation of carcass characteristics. Birds whose average weight was similar to that of the plot were selected, deprived of feed for $8 \mathrm{~h}$, slaughtered according to the recommendations of the animal ethics committee, plucked, and eviscerated. After the liver, the pancreas, and the carcass without neck, feet, and edible viscera were weighed, meat cuts were collected.

The carcass yield (\%) and the relative weights (\%) of liver and pancreas were calculated in relation to the live weight of the birds and the yields (\%) of breast and drumstick + thigh, in relation to the weight of the eviscerated carcass.

To remove the tibia, both drumsticks from each bird were removed and frozen in a freezer at $-20{ }^{\circ} \mathrm{C}$ for subsequent analysis. The parts were thawed in a refrigerator at $4{ }^{\circ} \mathrm{C}$ for $24 \mathrm{~h}$, and each drumstick, properly identified, was cooked in boiling water for $10 \mathrm{~min}$. Next, the tissues surrounding the bone were extracted with scalpels. Then the bones were prepared properly and the following characteristics were assessed: weight $(\mathrm{mg})$, using an electronic scale with $0.01 \mathrm{~g}$ precision and length $(\mathrm{mm})$, with a digital caliper. After obtaining these data, the Seedor index $\left(\mathrm{mg} \mathrm{mm}^{-1}\right)$ was calculated by dividing the bone weight $(\mathrm{mg})$ with bone length (mm) (Seedor et al., 1991).

Left tibias were used to determine bone resistance $\left(\mathrm{kgf} \mathrm{cm}^{-2}\right)$ and deformity $(\mathrm{mm})$ in a laboratory, using a triaxial mechanical press (Testop/Ronald top; Indústria e Comércio Ronald Top Ltda., Rio de Janeiro, RJ) with $150-\mathrm{kg}$ capacity. Bones were placed upright on a wooden support, held by their extremities, and then a compression force was applied by piston onto the center of each bone. The piston descent speed was $1.23 \mathrm{~mm} \mathrm{~min}^{-1}$. The maximum force applied on the bone to its rupture was considered the breaking strength $\left(\mathrm{kgf} \mathrm{cm}^{-2}\right)$, which was measured with a digital extensometer (543-682; Mitutoyo Sul Americana Ltda., São Paulo, SP). Bone deformity (mm) was measured by recording the flexibility of each bone in relation to its horizontal position until its rupture by the action of the applied force, using an analogical extensometer (2046-s; Mitutoyo Sul Americana Ltda., São Paulo, SP).

The right tibias were taken to the laboratory for drying in a forced-air ventilation oven at $55^{\circ} \mathrm{C}$ for $72 \mathrm{~h}$. Afterwards, they were ground in a ball mill, placed in plastic jars, and subsequently their dry matter and mineral matter contents were determined (Silva and Queiroz, 2002).

The statistical analyses of the data were carried out using the SAS software (Statistical Analysis System, version 8.2). Data were subjected to analysis of variance to evaluate the effect of treatments and test the factorial. Dunnet's test at $5 \%$ probability was used to compare the control treatment with each of the other treatments and the $t$ test at $5 \%$ probability was employed to compare the evaluated factors storage and level of inclusion.

\section{Results}

The acidity values obtained for NCNM and SCNM were, respectively, 4.66 and $6.16 \%$ in oleic acid; the peroxide values obtained for both types of meal were 0.0 meq kg-1 .

According to the results for the coefficient of metabolization and metabolizable energy of the experimental diets, significant differences among treatments were only found in the amount of metabolizable energy (Table 2). In the comparison of means by Dunnet's test at 5\% probability, the control diet showed significantly lower AME and AMEn values than the diets containing CNM.

When the effects of level of inclusion and type of CNM were evaluated, it was found that these factors had no significant interaction for the coefficients of 
metabolization or for the metabolizable energy values. However, regardless of the level of inclusion of the meal, the AME and AMEn contents of the diets containing NCNM increased compared with those determined for the diets containing SCNM. It was also found that irrespective of the type of meal, AMEn increased when the CNM in the diet was elevated from 12.5 to $25 \%$.

In the analysis of the performance data, there were significant differences among the treatments for feed intake and feed conversion (Table 3). In the comparison of means by Dunnet's test at 5\% probability, the birds fed the control diet displayed higher feed intake and because weight gain did not differ significantly, feed conversion was worse than that obtained by the birds fed diets containing CNM.

When the effect of level of inclusion and type of CNM was evaluated, it was observed that there was no significant interaction between these factors for the evaluated performance variables. Also, irrespective of the level of inclusion, the birds fed diets containing SCNM showed increased intake and worse feed conversion as compared with those consuming diets with NCNM. Weight gain was not influenced by level or type of CNM in the diet.

The carcass traits and relative weights of liver and pancreas of the quails were not influenced by the different treatments (Table 4).

In the analysis of the bone parameter data, it was found that the treatments did not affect length, weight, Seedor index, deformity or resistance of the tibia, or the amounts of DM and ash in the bones (Table 5).

\section{Discussion}

It was observed that the NCNM that arrived at the feed factory had acidity level of $4.66 \%$ in oleic acid. The high content of acids present in the nutshell liquid $(90 \%$ anacardic acid), the tannic acid (41.8\%) found in the nut skin (Pinheiro et al., 2002), and the fatty acids free of the lipid fraction of this byproduct ( $47 \%$ fat) might have contributed to this, since pieces of shell and fragments of skin are commonly found in different proportions in this byproduct (Soares et al., 2007). The higher acidity of SCNM compared with NCNM may be a consequence of the inappropriate storage of the nut in the field or in the processing industry, which promotes the action of microorganisms, thereby making it more susceptible to develop hydrolytic rancidity (Lopes et al., 2009). The results of the present research disagree with those obtained by Lopes et al. (2009), who did not observe an increase in the acidity index of CNM during the period of 35 days of storage.

The peroxide values obtained for NCNM and SCNM were null. This result may be associated with higher stability of the lipids contained in this feed to the effects of oxidation. Although CNM has a high percentage of

Table 2 - Coefficients of metabolization and energy value of diets for meat quails (Coturnix coturnix) fed different levels of inclusion of new cashew nut meal (NCNM) or the meal stored for 180 days (SCNM)

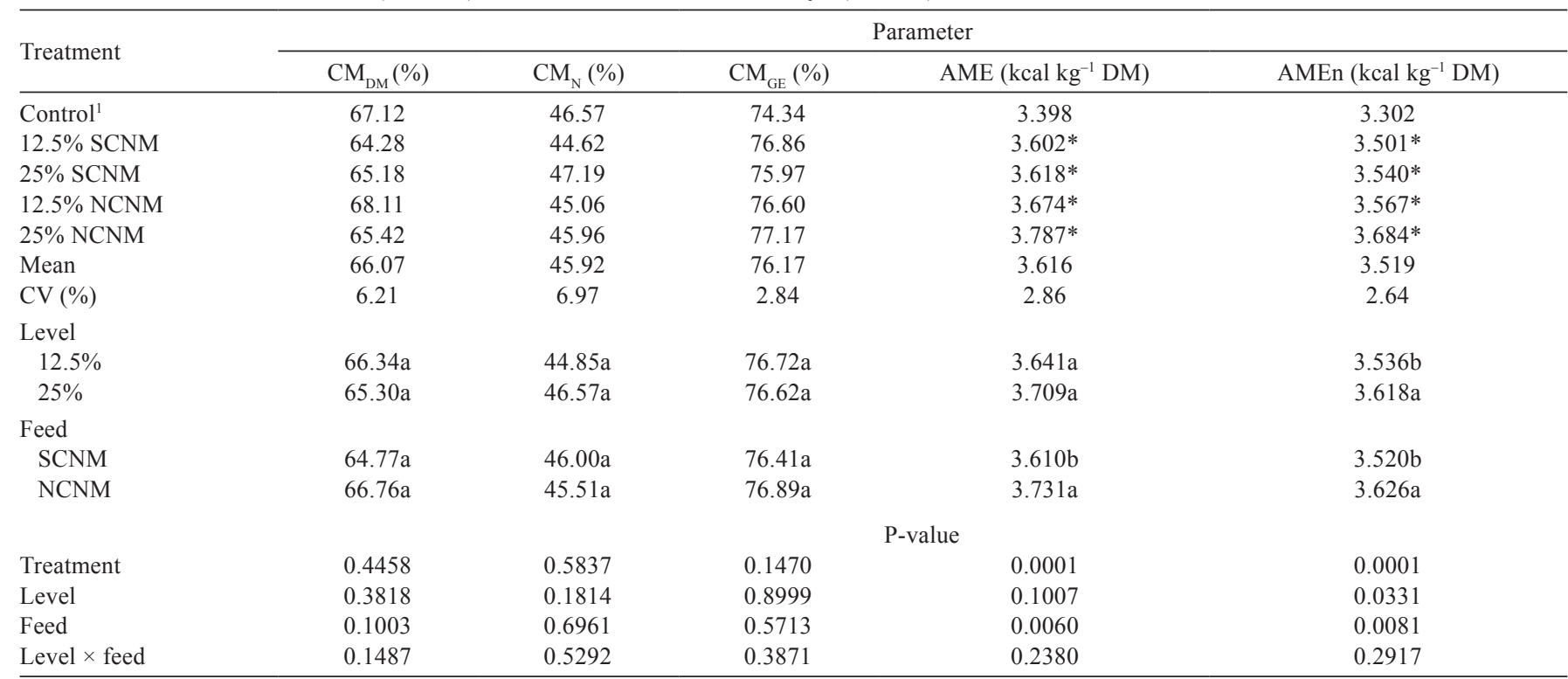

${ }^{1}$ Control: without cashew nut meal.

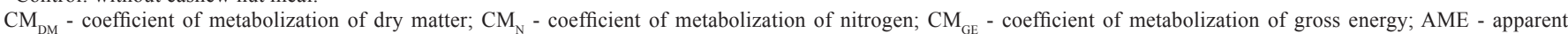
metabolizable energy; AMEn - apparent metabolizable energy corrected for the nitrogen balance; CV - coefficient of variation.

$\mathrm{a}, \mathrm{b}$ - Means within a column followed by the same letter do not differ by the $\mathrm{t}$ test at $5 \%$ probability.

*Differs from control by Dunnet's test at $5 \%$ probability. 
unsaturated fatty acids $(82.74 \%)$, the predominating acids are oleic $(60.30 \%)$ and linoleic $(21.53 \%)$, which are more stable to oxidation than linolenic acid (Lima et al., 2004). The presence of anacardic acid might also have contributed to SCNM protection, as it was proven to have antioxidant action and can be found in different proportions in the kernel, shell, and skin of the cashew nut (Trevisan et al., 2006). However, Lopes et al. (2009) reported signs of peroxidation (1.956 meq $\left.\mathrm{kg}^{-1}\right)$ in $\mathrm{CNM}$ when it arrived at

Table 3 - Performance of meat quails (Coturnix coturnix) fed diets containing new cashew nut meal (NCNM) or the meal stored for 180 days (SCNM)

\begin{tabular}{lccc}
\hline \multirow{2}{*}{ Treatment } & \multicolumn{3}{c}{ Parameter } \\
\cline { 2 - 4 } & $\begin{array}{c}\text { Feed intake } \\
\left(\mathrm{g} \mathrm{bird}^{-1}\right)\end{array}$ & $\begin{array}{c}\text { Weight gain } \\
\left(\mathrm{g} \mathrm{bird}^{-1}\right)\end{array}$ & $\begin{array}{c}\text { Feed conversion } \\
\text { ratio }\end{array}$ \\
\hline Control $^{1}$ & 721.99 & 207.59 & 3.49 \\
$12.5 \%$ SCNM & $646.92^{*}$ & 205.35 & $3.16^{*}$ \\
$25 \%$ SCNM & $670.93^{*}$ & 209.14 & $3.21^{*}$ \\
$12.5 \%$ NCNM & $597.25^{*}$ & 209.31 & $2.86^{*}$ \\
$25 \%$ NCNM & $591.12^{*}$ & 206.62 & $2.87^{*}$ \\
Mean & 646.34 & 207.50 & 3.12 \\
CV $(\%)$ & 5.85 & 6.97 & 7.03 \\
Level & & & \\
$12.5 \%$ & $624.00 \mathrm{a}$ & $207.13 \mathrm{a}$ & $3.02 \mathrm{a}$ \\
$25 \%$ & $627.96 \mathrm{a}$ & $207.78 \mathrm{a}$ & $3.02 \mathrm{a}$ \\
Feed & & & \\
SCNM & $658.00 \mathrm{a}$ & $207.10 \mathrm{a}$ & $3.19 \mathrm{a}$ \\
NCNM & $593.96 \mathrm{~b}$ & $207.86 \mathrm{a}$ & $2.87 \mathrm{~b}$ \\
& & & \\
Treatment & 0.0001 & 0.9855 & 0.0001 \\
Level & 0.8067 & 0.9180 & 0.9383 \\
Feed & 0.0006 & 0.8976 & 0.0015 \\
Level $\times$ feed & 0.2985 & 0.5885 & 0.6994 \\
\hline
\end{tabular}

${ }^{1}$ Control: without cashew nut meal.

$\mathrm{CV}$ - coefficient of variation.

$\mathrm{a}, \mathrm{b}$ - Means within a column followed by the same letter do not differ by the t test at $5 \%$ probability.

*Differs from control by Dunnet's test at $5 \%$ probability. the feed factory and a gradual increase in the peroxide value (2.013 meq $\mathrm{kg}^{-1}$ ) over the 35 days of storage.

As for the increase in the values of metabolizable energy in the diets containing CNM compared with the control diet, it is possible that the increased proportion of fat in the diets containing CNM contributed to these results, although the diets were calculated to be isoenergetic.

Some studies have demonstrated benefits of increasing the fat content in poultry diets related to the extra-caloric effect and to the extra-metabolic effect of fats, because of the lower heat increment of fats (Freitas et al., 2006).

The beneficial effects of increased fat in the diet could also justify the difference of $82 \mathrm{kcal}$ AMEn $\mathrm{kg}^{-1} \mathrm{DM}$ between the diets containing $12.5 \%$ and those containing $25 \%$ of inclusion. However, considering that the AME values did not differ significantly, it is more likely that the difference in AMEn occurred due to a difference in retention of nitrogen, since the difference between AME and AMEn for the diet containing 12.5 or $25 \%$ inclusion of CNM was 105 and $91 \mathrm{kcal} \mathrm{kg}^{-1} \mathrm{DM}$, respectively.

With regard to the effects of storage, inclusion of SCNM did not provide an increase in the amount of metabolizable energy in the diet at the same proportion found with addition of NCNM. This difference may be a result of the effects of the hydrolysis processes during storage, as demonstrated by the increase in the acidity index. The lipid peroxidation reduces the energy value of the feed, as a consequence of the destruction of fatty acids (Engberg et al., 1996).

The effects detected with inclusion of CNM on the metabolization of energy disagree with those obtained by Soares et al. (2007). The authors reported that inclusion of

Table 4 - Carcass traits and relative weights of liver and pancreas of meat quails (Coturnix coturnix) fed diets containing new cashew nut meal (NCNM) or the meal stored for 180 days (SCNM)

\begin{tabular}{|c|c|c|c|c|c|}
\hline \multirow{2}{*}{ Treatment } & \multicolumn{5}{|c|}{ Parameter } \\
\hline & Carcass $(\%)$ & Drumstick + thigh (\%) & Breast $(\%)$ & Liver $(\%)$ & Pancreas $(\%)$ \\
\hline Control $^{1}$ & 67.98 & 25.10 & 41.05 & 1.74 & 0.26 \\
\hline $12.5 \% \mathrm{SCNM}$ & 67.61 & 24.54 & 42.27 & 1.71 & 0.22 \\
\hline $25 \% \mathrm{SCNM}$ & 68.00 & 25.22 & 41.94 & 1.76 & 0.25 \\
\hline $12.5 \% \mathrm{NCNM}$ & 67.82 & 25.40 & 41.62 & 1.80 & 0.26 \\
\hline $25 \%$ NCNM & 66.73 & 25.46 & 41.08 & 1.93 & 0.25 \\
\hline Mean & 67.43 & 25.14 & 41.59 & 1.79 & 0.25 \\
\hline \multirow[t]{2}{*}{ CV (\%) } & 4.14 & 5.11 & 3.81 & 13.96 & 30.32 \\
\hline & & & P-value & & \\
\hline Treatment & 0.7076 & 0.3448 & 0.1897 & 0.3637 & 0.6228 \\
\hline Level & 0.6530 & 0.3003 & 0.2763 & 0.1798 & 0.6828 \\
\hline Feed & 0.5000 & 0.1264 & 0.0606 & 0.0595 & 0.1968 \\
\hline Level $\times$ feed & 0.3478 & 0.3793 & 0.7967 & 0.3352 & 0.3547 \\
\hline
\end{tabular}

${ }^{1}$ Control: without cashew nut meal

$\mathrm{CV}$ - coefficient of variation. 
Table 5 - Bone parameters of meat quails (Coturnix coturnix) fed diets containing new cashew nut meal (NCNM) or the meal stored for 180 days $(\mathrm{SCNM})$

\begin{tabular}{|c|c|c|c|c|c|c|c|}
\hline \multirow{2}{*}{ Treatment } & \multicolumn{7}{|c|}{ Parameter } \\
\hline & $\mathrm{TL}(\mathrm{mm})$ & TW (g) & TSI $\left(\mathrm{mg} \mathrm{mm}^{-1}\right)$ & TDF (mm) & $\mathrm{TR}\left(\mathrm{kgf} \mathrm{cm^{-2 } )}\right.$ & TDM (\%) & TASH (\%) \\
\hline Control $^{1}$ & 58.40 & 1.03 & 17.58 & 1.61 & 2.04 & 70.21 & 46.81 \\
\hline $12.5 \% \mathrm{SCNM}$ & 57.70 & 1.02 & 17.59 & 1.62 & 2.29 & 69.52 & 46.30 \\
\hline $12.5 \% \mathrm{NCNM}$ & 57.05 & 1.01 & 17.71 & 1.76 & 2.14 & 69.52 & 44.95 \\
\hline $25 \%$ NCNM & 56.83 & 0.99 & 17.44 & 1.49 & 1.96 & 67.32 & 46.10 \\
\hline Mean & 57.43 & 1.01 & 17.58 & 1.61 & 2.16 & 68.89 & 46.11 \\
\hline CV (\%) & & & & P-value & & & \\
\hline Treatment & 0.2178 & 0.9858 & 0.9997 & 0.8485 & 0.2981 & 0.6649 & 0.6556 \\
\hline Level & 0.2801 & 0.7224 & 0.8720 & 0.3323 & 0.5903 & 0.2269 & 0.5382 \\
\hline Feed & 0.3961 & 0.8797 & 0.9793 & 0.7127 & 0.0800 & 0.9753 & 0.3084 \\
\hline Level $\times$ feed & 0.5311 & 0.9358 & 0.8948 & 0.5507 & 0.4828 & 1.0000 & 0.5304 \\
\hline
\end{tabular}

${ }^{1}$ Control: without cashew nut meal.

TL - tibia length; TW - tibia weight; TSI - tibia Seedor Index; TDF - tibia deformity; TR - tibia resistance; TDM - tibia dry matter; TASH - ash content in the tibia (expressed in dry matter); CV - coefficient of variation.

up to $20 \%$ CNM did not influence the metabolizable-energy levels of the diets.

Because the bird voluntary intake of feed is regulated, within certain limits, by the intake of energy (Leeson and Summers, 2001), it can be inferred that the lower feed intake with the diets containing CNM than the control can be associated with the attempt of birds to regulate their intake of energy. This also explains the difference between the birds fed SCNM and NCNM. The small difference in AMEn between diets containing 12.5 and $25 \%$ inclusion, in turn, was not sufficient to influence intake.

Given that weight gain results from the ingestion and use of nutrients from the diet and that birds fed CNM showed a lower feed intake as compared with control, the fact that the inclusion of CNM did not result in a lower weight gain can be associated with the benefits of the greater presence of fat in these diets. In contrast, the problems of reduction in the use of the nutrients of the birds fed SCNM were compensated by the increased fed intake, guaranteeing weight gain to these birds. Dvorin et al. (1998) found that oils rich in polyunsaturated fatty acids are absorbed more easily and, therefore, have higher values of metabolizable energy, thus promoting a better bird performance.

Since feed conversion is obtained from the ratio between the feed intake and the weight gain, it can be inferred that the significant difference for this variable is the reflection of the results obtained for the feed intake and weight gain of birds. Thus, the lower feed intake of the birds fed diets containing CNM and the absence of variation in weight gain among the treatments reflected in better feed conversion values for the birds fed diets with inclusion of CNM. In contrast, because feed intake increased and weight gain had no significan variation, the birds fed SCNM showed worse result for feed conversion than those receiving diets containing NCNM.

The worse feed conversion for birds fed the stored meal in comparison to those fed the new meal indicates problems in the use of nutrients, caused by the hydrolytic reactions, given that acidity of cashew nut meal during storage was 6.16 (\% in oleic acid). However, although there was an increase in the levels of acidity and peroxide during the storage of CNM for 35 days, Lopes et al. (2009) did not observe differences in intake, weight gain, and feed conversion of broilers fed diets containing 15\% inclusion of this meal.

The effects of including CNM for meat quail performance partly agree with those reported for broilers. Ojewola et al. (2004) did not find significant effects among the treatments on feed intake or weight gain; however, feed conversion was better with the diets containing 25,50 , and $75 \%$ substitution of soy protein through the inclusion of $7.5,15$, and $22.50 \% \mathrm{CNM}$ in the diet, respectively, when compared with control. Freitas et al. (2006) did not observe any influence of diets with different levels of inclusion of CNM on feed intake, but weight gain was higher with inclusion of $15 \% \mathrm{CNM}$, whereas feed conversion improved with $10 \%$ inclusion. Oluwasola (2006) observed that final weight gain, daily weight gain, and retention of fat were significantly higher with increase in the levels of substitution of the protein from the soybean meal at up to $50 \%$ with inclusion of $28.3 \% \mathrm{CNM}$ in the diets.

Studying the effect of inclusion of a feed in the diet on carcass characteristics, Freitas et al. (2006) reported that if the nutritional value of the feed is evaluated properly, it is 
very unlikely that the carcass traits will be influenced by the inclusion of this feed in isonutritive diets. However, if the metabolizable energy value of a feed is underestimated, its inclusion in the diet may cause changes in the energy: protein ratio of the diet and thus lead to changes in carcass yield or even in the carcass cuts. In this context, it can be inferred that an increased amount of dietary metabolizable energy with addition of CNM or with the use of NCNM as compared with SCNM was not sufficient to cause significant changes in the carcass quality.

Some reports in the literature (Leeson and Summers, 2001) indicate that the high level of peroxides in the hepatic fat and the presence of many toxic compounds formed during oxidation may harm the liver epithelial cells. Moreover, severe changes in the normal fatty acid composition of the liver cause disturbances in the metabolism of the lipids, which result in alterations in the size of this organ (Bondi, 1988). Thus, the absence of variation in the relative weight of the liver of birds fed diets containing SCNM may be attributed to the low lipid peroxidation, as determined by the peroxide value.

The effects of addition of CNM on the carcass traits of quails agree with those reported for broilers. Freitas et al. (2006) found that the carcass traits were not influenced by inclusion of CNM in the diet and Lopes et al. (2009) observed that the carcass traits and relative weight of the liver of broilers were not influenced by inclusion of CNM stored for 35 days in the diet. However, Oluwasola (2006) found a significant increase in the weights of drumstick and thigh, wings, head, and abdominal fat of hens fed diets with up to $50 \%$ substitution of the protein from the soy of the diet by inclusion of $28.3 \%$ CNM. However, regarding the weights of liver and pancreas, the authors observed no significant differences between the different treatments.

The lower mineral use, especially of calcium and phosphorus, may lead to problems in growth and quality of the bone tissue of birds (Rath et al., 2000). Contrastingly, the presence of free radicals, found in peroxidized fats, may increase the osteolytic activity of osteoclasts, which promotes the destruction of bone crystals (Garret et al., 1990). In this context, the results obtained in the present study indicate that these possible effects did not translate into problems in the growth and quality of the bones of quails.

\section{Conclusions}

Although cashew nut meal stored for 180 days presents hydrolytic rancidity index around $6.16 \%$, its inclusion in quail feed at levels of up to $25 \%$ can be performed without causing problems to the performance, carcass characteristics, and bone quality parameters.

\section{Acknowledgments}

The authors thank Conselho Nacional de Desenvolvimento Científico e Tecnológico and Coordenação de Aperfeiçoamento de Pessoal de Nível Superior.

\section{References}

Anfar. 2005. Compêndio brasileiro de alimentação animal - Métodos analíticos. 2.ed. Sindirações (Sindicato Nacional da Indústria de Alimentação Animal), São Paulo, SP.

Bondi, A. A. 1988. Nutrición animal. Acribia, Zaragoza.

Cabel, M. C.; Waldroup, W.; Shermer, W. D. and Calabotta, D. F. 1988. Effects of ethoxyquin feed preservative and peroxide level on broiler performance. Poultry Science 67:1725-1730.

Dvorin, A.; Zoref, Z.; Mokady, S. and Nitsan, Z. 1998. Nutritional aspects of hydrogenated and regular soybean oil added to diets of broiler chickens. Poultry Science 77:820-825.

Engberg, R. M.; Lauridsen, C.; Jensen, S. K. and Jakobsen, K. 1996. Inclusion of oxidized vegetable oil in broiler diets. Its influence on nutrient balance and on oxidative status of broilers. Poultry Science 75:1003-1011.

Freitas, E. R.; Fuentes, M. F. F.; Santos Júnior, A.; Guerreiro, M. E. F. and Espíndola, G. B. 2006. Farelo de castanha de caju em rações para frangos de corte. Pesquisa Agropecuária Brasileira 41:1001-1006.

Garrett, R. I.; Boyce, B. F.; Oreffo, R. O. C; Bonewald, L.; Poser, J. and Mundy, G. R. 1990. Oxygen-derived free radicals stimulate osteoclastic bone resorption in rodent bone in vitro and in vivo. Journal of Clinical Investigation 85:632-639.

Leeson, S. and Summers, J. D. 2001. Nutrition of the chicken. 4 th ed. University Books, Canada.

Lima, A. C.; García, N. H. P. and Lima, J. R. 2004. Obtenção e caracterização dos principais produtos do caju. Boletim do Centro de Pesquisa de Processamento de Alimentos 22:133-144.

Lopes, I. R. V.; Fuentes, M. F. F.; Freitas, E. R.; Silva, R. B.; Lima, R. C. and Bezerra, R. M. 2009. Desempenho e características de carcaça de frangos de corte alimentados com rações contendo farelo de castanha de caju tratado ou não com antioxidante. Revista Brasileira de Zootecnia 38:1502-1508.

NRC - National Research Council. 1994. Nutrient requirements of poultry. 9th ed. National Academy Press, Washington, DC, USA.

Ojewola, G. S.; Okoye, F. C. and Agbakuru, I. 2004. Replacement value of cashew-nut meal for soyabean meal in finishing broiler chickens. International Journal of Poultry Science 3:513-516.

Oluwasola, A. J. 2006. Growth indices and muscle development in broiler-chickens fed equi-protein replacement of soyabean meal with discarded cashew nut meat. The Journal of Poultry Science 43:215-221.

Pinheiro, J. W.; Fonseca, N. A. N.; Silva, C. A.; Cabrera, L.; Bruneli, F. A. T. and Takahashi, S. E. 2002. Farelo de girassol na alimentação de frangos de corte em diferentes fases do desenvolvimento. Revista Brasileira de Zootecnia 31:1418-1425.

Rath, N. C.; Huff, G. R.; Huff, W. E. and Balog, J. M. 2000. Factors regulating bone maturity and strength in poultry. Poultry Science 79:1024-1032.

Rostagno, H. S.; Albino, L. F. T.; Donzele, J. L.; Gomes, P. C.; Oliveira, R. F.; Lopes, D. C.; Ferreira, A. S.; Barreto, S. L. T. and Euclides, R. F. 2011. Tabelas Brasileiras para aves e suínos: composição de alimentos e exigências nutricionais. 3.ed. UFV, Viçosa, MG. 
Sakomura, N. K. and Rostagno, H. S. 2007. Métodos de pesquisa em nutrição de monogástricos. FUNEP, Jaboticabal, SP.

Seedor, J. G.; Quartuccio, H. A. and Thompson, D. D. 1991. The biophosphanate alendronate (MK-217) inhibit bone loss due to ovariectomy in rats. Bone and Mineral Research 4:265-270.

Silva, D. J. and Queiroz, A. C. 2002. Análise de alimentos: métodos químicos e biológicos. 3.ed. UFV, Viçosa, MG.

Silva, R. B.; Freitas, E. R.; Fuentes, M. F. F.; Lopes, I. R. V.; Lima, R. C. and Bezerra, R. M. 2008. Composição química e valores de energia metabolizável subprodutos agroindustriais determinados com diferentes aves. Acta Scientiarum Animal Science 30:269-275.

Soares, M. B.; Fuentes, M. F. F.; Freitas, E. R.; Lopes, I. R. V.; Moreira, R. F.; Sucupira, F. S.; Braz, N. M. and Lima, R. C. 2007.
Farelo de amêndoa da castanha de caju na alimentação de codornas japonesas na fase de postura. Revista da Sociedade Brasileira de Zootecnia 36:1076-1082.

Trevisan, M. T. S.; Pfundstein, B.; Haubner, R.; Würtele, G.; Spiegelhalder, B.; Bartsch, H. and Owen, R. W. 2006. Characterization of alkyl phenols in cashew (Anacardium occidentale) products and assay of their antioxidant capacity. Food and Chemical Toxicology 44:188-197.

Venkatachalam, M. and Sathe, S. K. 2006. Chemical composition of selected edible nut seeds. Journal of Agricultural and Food Chemistry 54:4705-4714.

Wang, S. Y.; Bottje, W.; Maynard, P.; Dibner, J. and Shermer, W. 1997. Effects of Santoquim ${ }^{\circledR}$ and oxidized fat on liver and intestinal glutathione in broilers. Poultry Science 76:961-967. 